\title{
Prospective evaluation of estrogen receptor- $\beta$ in predicting response to neoadjuvant antiestrogen therapy in elderly breast cancer patients
}

\author{
Vera Cappelletti ${ }^{1}$, Luigi Celio ${ }^{2}$, Emilio Bajetta ${ }^{2}$, Arianna Allevi ${ }^{1}$, \\ Raffaella Longarini ${ }^{2}$, Patrizia Miodini ${ }^{1}$, Raffaella Villa ${ }^{1}$, Alessandra Fabbri ${ }^{3}$, \\ Luigi Mariani ${ }^{4}$, Riccardo Giovanazzi ${ }^{5}$, Emanuele Galante ${ }^{5}$, Marco Greco ${ }^{5}$ \\ and Maria Grazia Daidone ${ }^{1}$
}

\footnotetext{
${ }^{1}$ Department of Experimental Oncology, ${ }^{2}$ Medical Oncology B Unit, ${ }^{3}$ Department of Pathology, ${ }^{4}$ Unit of Medical Statistics and Biometry and ${ }^{5}$ Breast Surgery Unit, Istituto Nazionale per lo Studio e la Cura dei Tumori, Milan, Italy

(Requests for offprints should be addressed to Vera Cappelletti, Unit of Biomolecular Determinants of Prognosis and Response, Istituto Nazionale Tumori, Via Venezian 1, 20133 Milan, Italy; Email: vera.cappelletti@ istitutotumori.mi.it)
}

\begin{abstract}
It has been proposed that knowledge of estrogen receptor $\beta$ (ER- $\beta$ ) expression may refine estrogen receptor $\alpha(E R-\alpha)$ predictivity of response to endocrine therapy. We challenged this hypothesis in ER$\alpha$-positive breast cancers subjected to preoperative antiestrogen treatment. Forty-seven elderly ( $\geq 65$ years old) women with nonmetastatic, ER- $\alpha$-positive (by immunohistochemistry) primary breast cancers ( $>2 \mathrm{~cm}$ in diameter) entered a neoadjuvant hormone therapy protocol $(60 \mathrm{mg} /$ day toremifene for 3 months). ER- $\alpha$ and ER- $\beta$ (ERs) mRNA was determined by semiquantitative RT-PCR, before (on core needle biopsy) and after (on surgical specimens) neoadjuvant treatment. Study end points included: (1) relation between treatment response and ER mRNA expression; and (2) changes in ER expression after treatment. The response was clinically assessed as tumor size change at the end of the preoperative treatment. ER mRNA expression was assessable before and after treatment in 38 and 20 cases respectively. ER- $\beta$ was co-expressed with ER- $\alpha$ at variable levels and significantly correlated only with progesterone receptor $(P=0.0285)$. Objective clinical response, including patients with minor change ( $\geq 25-<50 \%$ tumor shrinkage after treatment), was documented in $68.4 \%$ of cases and was independent of ER- $\beta$ levels or changes. ER- $\alpha$ levels were higher in tumors from patients in complete remission than in those from women achieving partial response or minor change compared with non-responsive patients (median expression values: 801 versus 516 versus 320 arbitrary units) and were consistently down-regulated by preoperative treatment. We conclude that in this elderly patient population with ER- $\alpha$-positive tumors, ER- $\beta$ mRNA was neither predictive of response to preoperative toremifene nor provided additional information to the knowledge of ER- $\alpha$ mRNA levels, which, conversely, were directly correlated with likelihood of response.
\end{abstract}

Endocrine-Related Cancer (2004) 11 761-770

\section{Introduction}

Most breast tumors express the estrogen receptor (ER), herein referred to as ER- $\alpha$, which is associated with the likelihood of response to endocrine therapy and is considered, along with the progesterone receptor $(\mathrm{PgR})$, the only biomarker of unequivocal utility for hormonal treatment in the clinical setting (Goldhirsch et al. 1998 , National Institutes of Health Consensus Conference Statement 2000). However, whereas approximately $90 \%$ of patients with ER- $\alpha$-negative tumors do not benefit from hormone therapy, response to endocrine manipulations is also not observed in a fraction of ER- $\alpha$-positive tumors (Early Breast Cancer Trialist Collaborative Group 1992, 
Peto 2000). The long-time problem of improving accuracy of ER status as a predictor of response to endocrine therapy was supposed to be resolved when an additional ER, usually known as ER- $\beta$, was described in 1996 (Kuiper et al. 1996). However, available preclinical and clinical results showed that ER- $\beta$ knowledge added further uncertainty to the matter of estrogen-promoted stimulation of breast cancer cells (Speirs 2002).

It is clear that ER- $\beta$ and ER- $\alpha$ are co-expressed in the same cells and have the ability to form heterodimers with an intermediate transcriptional efficiency between $\alpha \alpha$ (high efficiency) and $\beta \beta$ (low efficiency) homodimers, but gene promoter studies gave contrasting hints about the result of such heterodimerizations (Cowley et al. 1997). Early studies emphasized the fact that for AP-1mediated effects, in the presence of ER- $\beta$ the signal of antiestrogens was opposite to that observed in the presence of ER- $\alpha$ (Paech et al. 1997). On the other hand, more recent studies suggest that ER- $\beta$ has a negative regulatory role on ER- $\alpha$-promoted transcription (Hall \& McDonnell 1999, Pettersson et al. 2000). The clinical implications of the early and late findings are in contrast, indicating ER- $\beta$ as a predictor of either unresponsiveness or responsiveness to hormones, in the case of almost equimolar or at least comparable expression of the two isoforms.

As regards clinical studies, most of them are simply correlative and indicate significant associations of ER- $\beta$ expression with factors related to aggressiveness (Speirs et al. 1999a,b) or to a favorable prognosis (Jarvinen et al. 2000). Such studies, mainly performed retrospectively on heterogeneous and/or limited case series, employed different strategies to quantify ER- $\beta$ expression. In fact, an accurate measure of ER- $\beta$ protein levels is still problematic, as available antibodies provide unreliable results with immunohistochemistry on fixed sections (Skliris et al. 2002, Speirs et al. 2002) and the use of individually prepared antibodies often hinders interlaboratory comparability (Speirs et al. 2004).

To assess the clinical usefulness of ER- $\beta$ information, we evaluated the predictive role of the separate prospective estimation of the ER- $\beta$ and ER- $\alpha$ isoforms on responsiveness to endocrine therapy within the context of a clinical study. Antiestrogens have been extensively evaluated as neoadjuvant therapy in elderly patients with breast cancer, and substantial responses of ER-positive primary tumors over a 3-month period have been reported in older patients (Cheung \& Robertson 2001). Based on such evidence, a trial of short-term preoperative therapy with the antiestrogen toremifene in elderly women with operable or locally advanced breast cancer was conducted in order to investigate the relationship between ER- $\beta$ expression and the likelihood of response to endocrine therapy. However, in this series of ER- $\alpha$ positive tumors, ER- $\beta$ mRNA proved to be neither predictive of response to preoperative antiestrogen treatment nor did it provide additional information to that already provided by ER- $\alpha$ expression.

\section{Patients and methods}

\section{Study design}

The clinical protocol was an open-label, single-center, prospective study in which women, aged 65 years or older, with operable or locally advanced breast cancer received preoperative endocrine therapy with toremifene for 3 months. At the end of the study period, only patients who refused surgery continued on study medication until disease progression. Study objectives were (1) to evaluate the predictive role of the separate estimation of pretreatment ER- $\beta$ and ER- $\alpha$ expression on response to antiestrogen therapy; and (2) to assess ER- $\beta$ and ER- $\alpha$ modulation within the primary tumor following toremifene treatment.

\section{Eligibility and clinical treatment}

Women aged 65 years or older with invasive ER- $\alpha$ positive ( $>10 \%$ immunostained malignant cells), operable breast carcinoma larger than $2 \mathrm{~cm}$ in diameter on the mammogram (T2, T3, N0-1, M0) or locally advanced disease (T4b, N0-1, M0) entered the study. Tumor specimens for diagnosis and immunohistochemical assessment (ER- $\alpha$, PgR) or molecular determinations (ER- $\beta$ and ER- $\alpha$ mRNA) were obtained by 3-4 core needle biopsies before patient enrolment in the clinical study. At the same time, patients were screened for eligibility based on medical history, including concomitant medication, full physical examination, laboratory determinations, clinical tumor size by calipers, and by chest X-rays, bone scan and liver ultrasound examinations to confirm the absence of overt metastases. Patients were also required to be fit for surgery and were not to have received any prior treatment for breast cancer or be taking hormone preparations at the time of the study. No other systemic treatment for breast cancer in addition to toremifene was allowed. Approval for the study was given by the local Ethics Committee, and written informed consent, which also included a sentence confirming intention to donate to the Istituto Nazionale Tumori of Milan the leftover tissue after diagnosis for the present and for future research, was obtained from each patient.

Toremifene (Fareston, Schering Plough, Bulkham, Australia) was administered at a dose of $60 \mathrm{mg}$ once daily for 3 months. 
During the treatment period, each patient was carefully monitored at monthly intervals at the Outpatient Clinic of the Department of Medical Oncology of the Istituto Nazionale Tumori in order to estimate tumor size and check drug intake.

Successive patients were referred to the breast surgeon. Surgery consisted of modified radical mastectomy or quadrantectomy and axillary node dissection. Sentinel lymph node biopsy was not performed in N0 cases due to tumor dimensions (Veronesi et al. 2003).

\section{Efficacy assessment}

The percentage of tumor shrinkage from baseline was used to assess objective clinical response 3 months after starting toremifene treatment. Tumor size was calculated as the product of the two largest diameters clinically measured by calipers. All the patients were clinically assessed by two investigators ( $\mathrm{LC}$ and $\mathrm{RL}$ ). Clinical response was classified according to WHO criteria, except that tumors reduced by $\geq 25 \%$ but less than $50 \%$ in size were classified as minor change (MC). Complete response (CR) was defined as the disappearance of any measurable disease after 3 months, partial response (PR) was defined as a reduction of more than $50 \%$ in bidimensional diameter product, no change (NC) was defined as a reduction of less than $25 \%$ or an increase in size of less than $25 \%$, and progression of disease (PD) was defined as an increase of more than $25 \%$. In accord with criteria previously reported to evaluate clinical response to neoadjuvant hormonal treatment (Geisler et al. 2001), all the patients who experienced a major response (CR or $\mathrm{PR}$ ) or an MC were defined as responders, whereas all the patients with NC or a PD were defined as non-responders.

\section{Core needle breast biopsy}

Breast biopsy was performed through a small skin incision with a 14-gauge needle by means of an automatic device which was fired 3-4 times into the lesion to collect sufficient amount of tissue for analysis. Tissue collected for histological procedures was immediately fixed in formaldehyde, and tissue for molecular determinations was snap frozen in liquid nitrogen under sterile conditions to avoid contamination with RNase. Frozen tumors were not microdissected for molecular analyses but only those containing $>70 \%$ neoplastic cells (assessed from previous hematoxylin \& eosin frozen control) were processed for the study. To assess the comparability of ER mRNA expression levels in core needle biopsies and surgical specimens, as well as their changes over time in the absence of intercurrent treatments, preliminary experiments were carried out (a) on surgical tumor specimens and the core needle biopsy obtained ex vivo from the same material and (b) on tumor specimens obtained from diagnostic surgery and by the following radical intervention within a 3-week interval, without any intercurrent treatment.

\section{Determination of ER- $\beta$ and ER- $\alpha$ mRNA expression}

Core needle biopsies were stored in liquid nitrogen fumes until use. Samples were pulverized with a dismembrator (Braun Melsungen AG, Melsungen, Germany), and total RNA was extracted using the commercially available Trizol reagent (Life Technologies, Inc. Grand Island, NY, USA). One microgram total RNA was reverse transcribed using the commercially available 1st strand cDNA synthesis kit (RT-PCR (AMV), Roche Diagnostics, Mannheim, Germany) after incubation at $65^{\circ} \mathrm{C}$ for 15 min to remove secondary RNA structures, according to the manufacturer's instructions. Amplification of cDNA was carried out using the following primers. For ER- $\beta$ (Dotzlaw et al. 1999): sense (S) 5'-GTC CAT CGC CAG TTA ATC ACA TC-3', located in ER- $\beta$ 130-151; antisense (AS) 5'-GCC TTA CAT CCT TCA CAC GA$3^{\prime}$ (located in 371-352), giving an amplification product of 242 bp spanning the A/B domain of the protein. For ER- $\alpha$ (Dotzlaw et al. 1997): sense 5'-CAG GGG TGA AGT GGG GTC TGC TG-3' (corresponding to exon 4, nucleotides 1060-1083 (Green et al. 1986)); antisense 5'ATG CGG AAC CGA GAT GAT GTA GC-3' (priming in exon 6, nucleotides 1520-1543), giving an amplification product of $483 \mathrm{bp}$. For $\beta$-actin: sense 5'-ACA CTG TGC CCA TCT ACG AGG-3'; antisense 5'-AGG GGC CGG ACT CGT CAT ACT-3', giving an amplification product of $600 \mathrm{bp}$.

The PCR $(20 \mu \mathrm{l})$ contained PCR buffer $(10 \mathrm{mM}$ Tris$\mathrm{HCl}, \mathrm{pH} 8.3,50 \mathrm{mM} \mathrm{KCl}), 0.75 \mu \mathrm{M}$ each of dNTP, $1.6 \mathrm{mM} \mathrm{MgCl}_{2}, 4 \mathrm{ng} / \mu \mathrm{l}$ each of ER- $\beta \mathrm{S} / \mathrm{ER}-\beta \mathrm{AS}$ primers or $4 \mathrm{ng} / \mu \mathrm{l}$ each of ER- $\alpha \mathrm{S} / \mathrm{ER}-\alpha \mathrm{AS}$ primers and $0.125 \mathrm{ng} / \mu \mathrm{l}$ or $0.250 \mathrm{ng} / \mu \mathrm{l}$ (in the case of ER- $\alpha$ ) of $\beta$-actS $/ \beta$-actAS primers, 1 unit/tube Gold Taq DNA polymerase, $1 \mu$ of the mixture obtained by retrotranscription of $1 \mu \mathrm{g}$ RNA, and $1 \mu \mathrm{Ci}\left[{ }^{32} \mathrm{P}\right] \alpha \mathrm{dCTP}$ (specific activity, $110 \mathrm{TBq} / \mathrm{mmol}$ ) in a final volume of $20 \mu \mathrm{l}$.

The amplification conditions were as follows. ER- $\alpha$ : a single step of $10 \mathrm{~min}$ at $95^{\circ} \mathrm{C}$ to activate the enzyme, followed by 20 cycles of denaturation at $94^{\circ} \mathrm{C}$ for $1 \mathrm{~min}$, annealing at $60^{\circ} \mathrm{C}$ for $30 \mathrm{~s}$, and elongation at $72^{\circ} \mathrm{C}$ for $1 \mathrm{~min}$. ER- $\beta$ : a single step of $10 \mathrm{~min}$ at $95^{\circ} \mathrm{C}$ to activate the enzyme, followed by 28 cycles of denaturation at $94^{\circ} \mathrm{C}$ for $30 \mathrm{~s}$, annealing at $60^{\circ} \mathrm{C}$ for $30 \mathrm{~s}$, and elongation at $72^{\circ} \mathrm{C}$ for $30 \mathrm{~s}$. Blanks included the substitution of RNA or cDNA with distilled water and were consistently negative. Conditions for co-amplification were accurately determined with respect to primer concentration to guarantee 
comparable amplification efficiencies between the highly expressed standard and the target gene expressed at lower levels (data not shown). Linearity of the amplification reaction with respect to cycle number and cDNA amount was verified to give semiquantitative estimates of the amount of messengers. Each PCR amplification was performed in triplicate.

Radioactive PCR products were separated on a $6 \%$ polyacrylamide gel under non-denaturating conditions. Gels were dried, and the intensity of the radioactive signal was detected using a phosphoroimager (Thypoon Scanner, Molecular Dynamics/Amersham Biosciences, Piscatway, NJ, USA)

To quantitate ER- $\beta$ and ER- $\alpha$ mRNA levels, amplifications in clinical samples were run in triplicate, including in each amplification set two calibrators called high $(\mathrm{H})$ and low (L) expressors respectively for ER- $\beta$ $\left(\mathrm{H}_{\beta}, \mathrm{L}_{\beta}\right)$ and for ER- $\alpha\left(\mathrm{H}_{\alpha}, \mathrm{L}_{\alpha}\right) . \mathrm{H}_{\beta}$ and $\mathrm{L}_{\beta}$ calibrators were obtained from T47D cells respectively treated with $0.1 \mu \mathrm{M}$ bisphenol $\mathrm{A}$, which proved to enhance ER- $\beta$ mRNA expression (Cappelletti et al. 2003), and with vehicle alone, whereas $\mathrm{H}_{\alpha}$ and $\mathrm{L}_{\alpha}$ were obtained from T47D and BT20 cells respectively. The variability coefficient for triplicates was less than $10 \%$. Target-gene mean densitometric signals (normalized for $\beta$-actin expression) were expressed in arbitrary units as percentages with respect to $\mathrm{H}_{\alpha}$ and $\mathrm{H}_{\beta}$ and used for all clinicohistopathological correlations. The $\mathrm{H} / \mathrm{L}$ ratio calculated in each amplification set was used to monitor the interexperimental variability. For nucleic acid extraction and amplification by PCR we participated in an external quality assurance program recently activated in Italy (Paradiso et al. 2002, Casini Raggi et al. 2003) to assess the performance of cancer biomarkers of potential clinical relevance.

\section{Immunohistochemistry}

Four $2 \mu \mathrm{m}$ thick sections of formalin-fixed core biopsies were used for immunohistochemistry. ER- $\alpha$ ID5 (1:100) and PgR 636 (1:100) antibodies (Dako A/S DK 2600, Glostrup, Denmark) were used for ER- $\alpha$ and PgR respectively. Heat-induced epitope antigen retrieval was performed in citrate buffer using an autoclave. Endogenous peroxidase was blocked by a $3 \% \mathrm{H}_{2} \mathrm{O}_{2}$ solution for 5 min following treatment with normal goat serum 1:50 to prevent nonspecific binding. Samples were automatically processed using the Dako Autostainer Universal Staining System. Slides were incubated with the appropriate concentration of primary antibody for $1 \mathrm{~h}$ at room temperature. After application of biotinylated secondary antibodies (Chemate Detection Kit, peroxidase/3,3'-diaminobenzidine, DakoCytomation, Glostrup, Denmark), slides were treated with the chromogen (3,3'-diaminobenzidine, DAKOCytomation) and counterstained with hematoxylin. As a negative control, the primary antibody was replaced with a non-immune serum from the same species in which the primary antibody was produced. Appropriate cases with known reactivity for each antibody applied were used as positive controls. Immunostained slides were evaluated as previously described (Moliterni et al. 2003). Sections were scored positive for ER- $\alpha$ and PgR when more than $10 \%$ of the tumor cells were labeled.

\section{Data analysis}

Sample sizing for the clinical prospective study was calculated according to the mini-max two-stage design developed by Simon (1989) based on testing the null hypothesis that the true response probability, $p$, is less than some uninteresting level $\mathrm{p}_{0}\left(\mathrm{H}_{0}: \mathrm{p} \leq \mathrm{p}_{1}\right)$ against the alternative hypothesis that $\mathrm{P}$ is at least less than the desiderable target level $\mathrm{p}_{1}\left(\mathrm{H} 1: \mathrm{p} \leq \mathrm{p}_{1}\right)$. According to such calculations, and assuming: (1) a type I error probability of $0.10,(2)$ a power of $90 \%,(3)$ a $\mathrm{p}_{0}$ level of 0.30 and (4) a $\mathrm{p}_{1}-\mathrm{p}_{0}$ difference of $0.20\left(\mathrm{p}_{1}=0.50\right)$, the required sample size for the clinical study was 39 evaluable cases. For the biological study, we expected that 30 patients (between $70 \%$ and $80 \%$ of the whole sample) would have been assessable in terms of ER isoform expression. With this number, we estimated that a two-sided test at the 5\% significance level would yield a high power $(\geq 90 \%)$ for a Pearson correlation coefficient of \pm 0.56 or greater between ER- $\beta$ expression and the degree of change in tumor size.

The association between ER- $\beta$ and ER- $\alpha$ mRNA with clinico-pathological and biologic variables or clinical response was assessed by means of the Wilcoxon rank sum test and chi-squared test, with Yate's correction when appropriate. The association between ER isoforms as well as between the degree of change in tumor size and ER isoform expression was assessed by computing the Pearson correlation coefficient, after logarithmic transformation of ER levels to approximate a normal distribution.

Statistical analysis was carried out with the SAS package (version 6.12; SAS Institute, Cary, NC, USA), and all $P$ values were two sided.

\section{Results}

\section{Patient characteristics and clinical response}

Forty-seven patients entered the clinical study, but only 38 cases were assessable for biological evaluations. Patient characteristics and tumor response for the latter are shown in Table 1 . The median patient age was 78 years 
Table 1 Clinical and patho-biological characteristics of cases that entered the biological study.

\begin{tabular}{lc}
\hline & No. of patients (\%) \\
\hline Age (years) & \\
$\leq 75$ & $7(18)$ \\
$75-85$ & $21(55)$ \\
$>85$ & $10(27)$ \\
Clinical tumor size & \\
T2 & $35(92.1)$ \\
T3 & $2(5.3)$ \\
T4 & $1(2.6)$ \\
Clinical nodal status & \\
$N_{0}$ & $25(66)$ \\
$N_{+}$ & $13(34)$ \\
Histotype & \\
CDI & $21(55.3)$ \\
CLI & $3(7.9)$ \\
Infiltrating carcinoma & $14(36.8)$ \\
Grading & \\
G2 & $26(68.4)$ \\
G3 & $5(13.2)$ \\
Not assessable & $7(18.4)$ \\
PgRICA & \\
Negative & $7(18.4)$ \\
Positive & $30(78.9)$ \\
Not assessable & $1(2.7)$ \\
Objective clinical response & \\
CR+PR+MC & $26(68.4)$ \\
NC+PD & $12(31.6)$ \\
\hline
\end{tabular}

CDI, infiltrating ductal carcinoma; CLI, infiltrating lobular carcinoma; PgRICA, progesterone receptor immunocytochemical assay; CR, complete response; PR, partial response; MC, minor change; NC, no change; PD, progression of disease.

(range, 65-90 years), and most of the tumors were classified as T2 and did not exhibit clinical nodal involvement. The median clinical tumor diameter was $3.0 \mathrm{~cm}$ (range, $2.1-6.0 \mathrm{~cm}$ ). There was no early progression while on treatment, and 25 of the 38 patients for whom pretreatment specimens were assessable for ERs mRNA determination underwent surgery after the threemonth course of toremifene therapy.

At the end of the treatment period, tumor shrinkage was evident in 26 patients (26 of $38,68.4 \%$ ): a CR was achieved in 3 patients $(7.9 \%)$, PR in $13(34.2 \%)$, and MC in $10(26.3 \%)$. The NC category included 10 patients $(26.3 \%)$, and $2(5.3 \%)$ patients exhibited PD.

\section{In vitro determinations}

The median tissue weight was $20 \mathrm{mg}$ (range, $8-30 \mathrm{mg}$ ) for the core biopsy obtained from the 47 cases who entered the clinical study and $230 \mathrm{mg}$ (range, $100-450 \mathrm{mg}$ ) for the corresponding surgical material, obtained from the 25 patients who accepted to undergo surgery after comple-
Table 2 Expression of ER- $\beta$ and ER- $\alpha$ mRNA (expressed in arbitrary units as percentage of $\mathrm{H}_{\beta}$ and $\mathrm{H}_{\alpha}$ ) as a function of clinical and patho-biological variables.

\begin{tabular}{lccccc}
\hline & No. $\begin{array}{c}\text { Median ER- } \beta \\
\left(\% \text { of } \mathrm{H}_{\beta}\right)\end{array}$ & $\boldsymbol{P}$ & $\begin{array}{c}\text { Median ER- } \alpha \\
\left(\% \text { of } \mathrm{H}_{\alpha}\right)\end{array}$ & $\boldsymbol{P}$ \\
\hline $\begin{array}{l}\text { Age (years) } \\
\leq 75\end{array}$ & 7 & 96 & & 353 & \\
$75-85$ & 21 & 80 & 0.71 & 388 & 0.09 \\
$\quad>85$ & 10 & 80 & & 714 & \\
$\begin{array}{l}\text { Clinical nodal status } \\
\quad N_{0}\end{array}$ & 25 & 97 & 0.95 & 540 & 0.14 \\
$N_{+}$ & 13 & 84 & & 346 & \\
$\begin{array}{l}\text { Grading } \\
\text { G2 }\end{array}$ & 26 & 82 & 0.81 & 399 & 0.18 \\
$\quad \begin{array}{l}\text { G3 } \\
\text { PgRICA }\end{array}$ & 5 & 48 & & 714 & \\
$\quad$ Negative & 7 & 45 & 0.03 & 388 & 0.52 \\
Positive & 30 & 98 & & 514 & \\
\hline
\end{tabular}

PgRICA, progesterone receptor immunocytochemical assay. ${ }^{\mathrm{a}}$ For grading and PgRICA, information was not available on all the cases.

tion of the neoadjuvant treatment and whose residual tumor material was sufficient for the diagnosis and laboratory studies. Sufficient and good quality RNA, assessed on the basis of a standard electrophoretic check and of $\beta$-actin mRNA expression, was obtained from 38 of the 47 core biopsies and from 20 of the 25 surgical specimens. The yield of extracted RNA was lower from core biopsies (median value, $32.1 \mu \mathrm{g}$; range, 2.4-128.8 $\mu \mathrm{g}$ ) than from surgical specimens (median value, $100.7 \mu \mathrm{g}$; range, $17.7-289.8 \mu \mathrm{g}$ ). Core needle biopsies contained variable levels of ER- $\beta$, ranging from 9 to $903 \% \mathrm{H}_{\beta}$ with a median level of 84 . As regards ER- $\alpha$ mRNA, pretreatment values ranged between 73 and $1760 \% \mathrm{H}_{\alpha}$ with a median value of 514 .

In this subset of ER- $\alpha$-positive (by immunohistochemistry) cancers from elderly patients, ER- $\beta$ mRNA levels were unrelated to patient age, tumor grade or nodal status, whereas a direct association with $\mathrm{PgR}$ expression was observed $(P=0.0285)$. In fact, tumors defined as PgR-positive had an ER- $\beta$ expression twofold that of PgR-negative tumors (Table 2). Conversely, ER- $\alpha$ mRNA levels were suggestive of a direct association with patient age and an inverse association with clinical node status (Table 2). A weak and statistically not significant positive association between ER- $\beta$ and ER- $\alpha$ mRNA expression was observed $(r=0.12, P=0.47)$.

\section{Association between ER mRNA and clinical response to toremifene}

The relationship between pretreatment ER- $\beta$ mRNA expression and clinical response to preoperative treatment 


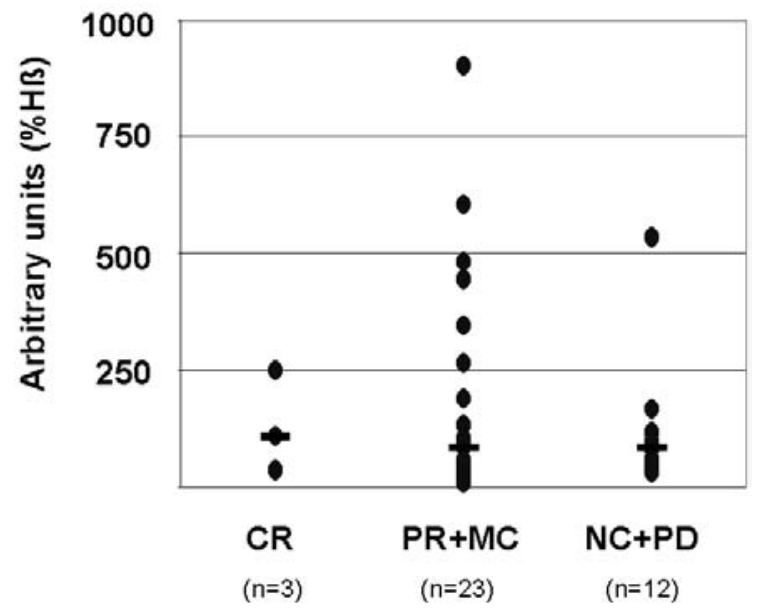

Figure 1 Scatter diagram of ER- $\beta$ mRNA levels according to patient treatment response. For each set of data (complete response $(\mathrm{CR})$, partial response/minor change (PR/MC), no change/progression of disease (NC/PD)), median values are also reported (horizontal line). ER- $\beta$ mRNA levels are expressed in arbitrary units as percentages of $\mathrm{H}_{\beta}$ and represent the mean of triplicate determinations.

with toremifene is shown in Fig. 1. The distribution of ER$\beta$ mRNA levels was similar for tumors from patients with $\mathrm{CR}, \mathrm{PR}$ and $\mathrm{MC}$, and no response (NC and $\mathrm{PD}$ ) (median values 108 vs 85 vs $84 \% \mathrm{H}_{\beta}$ respectively). However, we also carried out analysis according to standard WHO criteria (i.e. $\mathrm{CR}+\mathrm{PR}$ vs $\mathrm{NC}+\mathrm{PD}$ ) and obtained superimposable results (data not shown). Results were similar when individual experimental data were considered in relation to treatment response and when tumors were subdivided as low and high expressors using the median ER- $\beta$ mRNA value as a cutoff. In the latter case, $53.8 \%$ of tumors from responsive patients were high ER- $\beta$ expressors compared with $41.7 \%$ of tumors from non-responsive patients $\left(\chi^{2}=0.49\right.$, not significant $)$.

Although all patients had ER- $\alpha$-positive tumors as defined at the protein level by immunohistochemistry, we also evaluated the relationship between ER- $\alpha$ mRNA expression and treatment response. Median ER- $\alpha$ mRNA levels were higher in patients achieving CR $\left(801 \% \mathrm{H}_{\alpha}\right)$ and gradually decreased in patients who responded to treatment partially $\left(516 \% \mathrm{H}_{\alpha}\right.$ in the $\mathrm{PR}+\mathrm{MC}$ category) or not at all (320\% $\mathrm{H}_{\alpha}$ in the $\mathrm{NC}+\mathrm{PD}$ category) (Fig. 2). However, median ER- $\alpha$ mRNA levels did not differ significantly between responders and nonresponders (549 $\% \mathrm{H}_{\alpha}$ vs $\left.320 \% \mathrm{H}_{\alpha}, P=0.13\right)$. By dichotomizing data in high and low expressors using the median ER- $\alpha$ mRNA value as a cutoff, $53.8 \%$ of responsive patients were classified as high ER- $\alpha$ expressors, whereas $36.4 \%$ of nonresponsive patients were characterized by high ER- $\alpha$ levels $\left(\chi^{2}=0.37\right.$, not significant $)$.

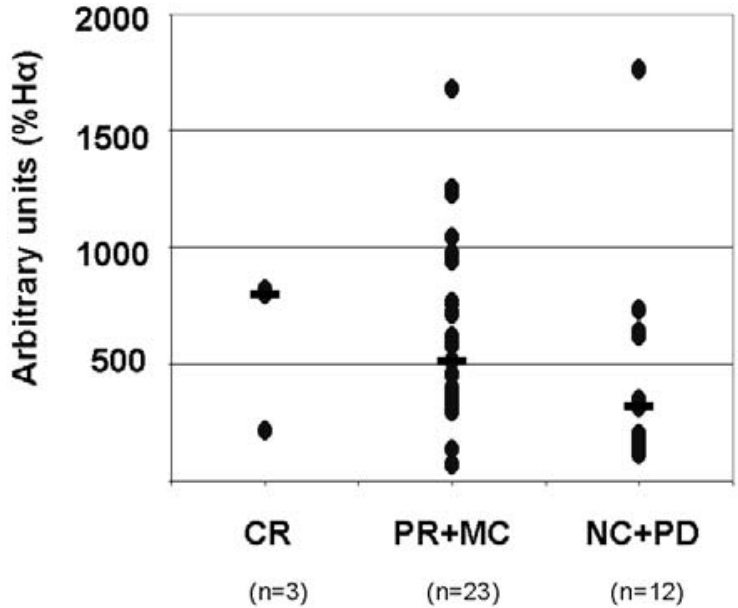

Figure 2 Scatter diagram of ER- $\alpha$ mRNA levels according to patient treatment response. For each set of data (complete response $(\mathrm{CR})$, partial response/minor change (PR/MC), no change/progression of disease (NC/PD)), median values are also reported (horizontal line). ER- $\alpha$ mRNA levels are expressed in arbitrary units as percentages of $\mathrm{H}_{\alpha}$ and represent the mean of triplicate determinations.

The association between ERs and tumor response was also investigated by considering tumor size variations on a continuous scale. The Pearson correlation coefficient showed a weak and statistically not significant, positive association between ER- $\alpha$ mRNA expression and the degree of reduction in tumor size $(r=0.24, P=0.15)$. The association between ER- $\beta$ mRNA expression and the reduction in tumor size was also not significant, but with a trend in the opposite direction $(r=-0.04, P=0.80$ $r=-0.11, P=0.53$ when considering the partial correlation coefficient adjusted for ER- $\alpha$ ).

Before studying treatment-induced changes in mRNA levels, ER- $\beta$ and ER- $\alpha$ were determined on biopsies and surgical samples obtained from the same patient in a 3week interval in the absence of any intercurrent treatment, and variations between ER levels in sample pairs were lower than 30\% (Fig. 3). Such a value was used to define biologically relevant variations when post- and pretreatment ER mRNA levels were compared. Superimposable levels of ER mRNA were also observed in surgical samples and core biopsies obtained ex vivo at the same time (data not shown).

Changes in ER expression following neoadjuvant treatment were assessed in the subset of 20 patients in which matched ERs mRNA data were available (11 responders and 9 nonresponders) (Fig. 4). Overall, median ER- $\beta$ levels in surgical specimens and in core biopsies were comparable $\left(101 \% \mathrm{H}_{\beta}\right.$ vs $\left.148 \% \mathrm{H}_{\beta}, P=0.13\right)$, whereas median ER- $\alpha$ levels of surgical samples were about four times lower than those of core biopsies (72\% $\mathrm{H}_{\alpha}$ vs $\left.320 \% \mathrm{H}_{\alpha}, P<0.0001\right)$. When post-treatment ER 


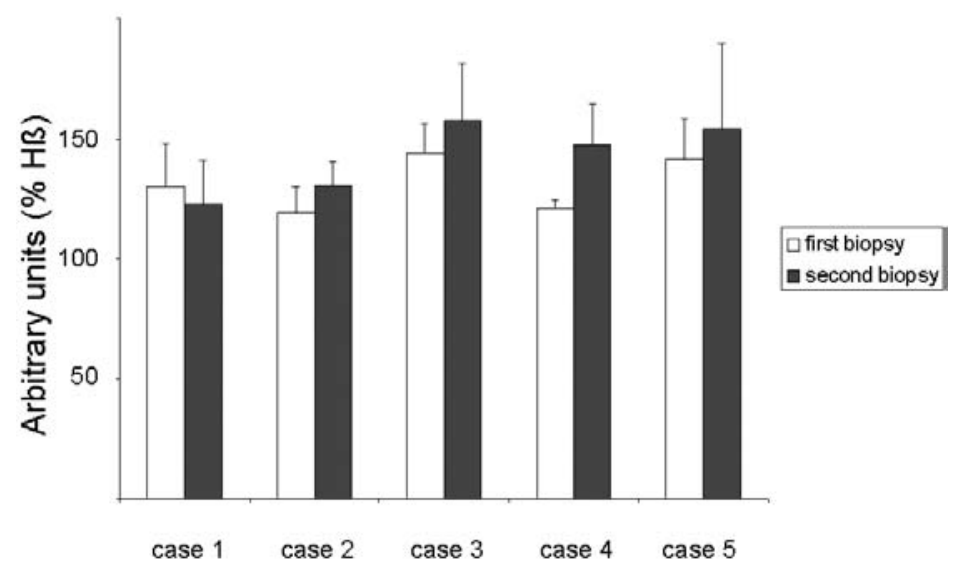

Figure 3 ER- $\beta$ levels determined in triplicate in paired samples from the five patients obtained at surgical diagnosis (open bars) and following radical intervention (solid bars) within a 3-week interval, without any intercurrent treatment.

modulations were analyzed in individual patients, $25 \%$ of patients experienced an up-regulation (increase greater than $30 \%$ in mRNA level) of ER- $\beta$ mRNA, $25 \%$ did not show any biologically significant change, and in 50\% ER$\beta$ levels were down-regulated (decrease greater than $30 \%$ in mRNA level) after toremifene treatment. The type of variation, summarized in Table 3 , did not correlate with treatment response. However, it should be emphasized that for this analysis 9 of 13 patients exhibiting a PR and 3 of 10 with MC were excluded for the non-availability of tissue specimens following neoadjuvant treatment compared with only 3 of the 12 nonresponders. For ER- $\alpha$, biologically significant reductions were observed in all the cases, regardless of treatment response.

\section{Discussion}

The clinical role of ER- $\beta$ in breast cancer appears controversial on the basis of published results. Inconsistencies among studies are due to heterogeneity in the case series under investigation (in terms of number of cases, clinical stage and treatment), biological end points

\section{$E R-\beta$}
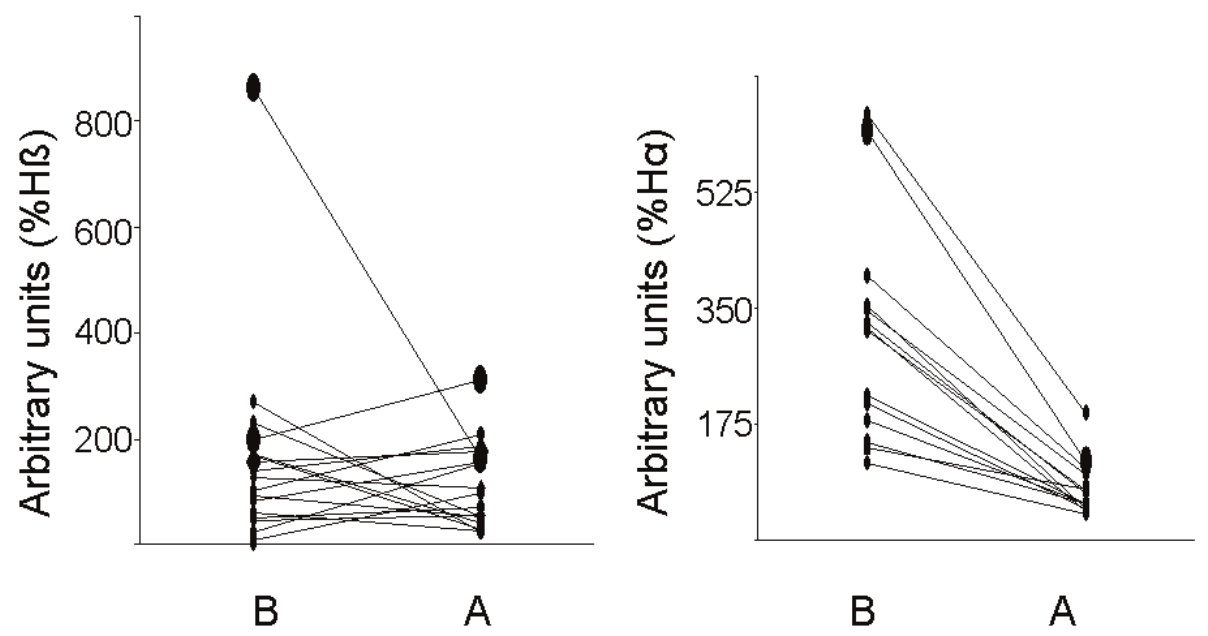

Figure 4 Treatment-induced variations of ER- $\beta$ and ER- $\alpha$ mRNA levels in the 20 cases for whom pre- and post-treatment ER mRNA was assessable. ER- $\beta$ and ER- $\alpha$ were determined in triplicate before (B) and after (A) treatment and expressed in arbitrary units as percentage of $\mathrm{H}_{\beta}$ and $\mathrm{H}_{\alpha}$ respectively. 
Table 3 ER- $\beta$ mRNA variations following toremifene treatment as a function of clinical response in the 20 cases for whom preand post-treatment ER mRNA was assessable.

\begin{tabular}{lcc}
\hline & \multicolumn{2}{c}{ Objective clinical response } \\
\cline { 2 - 3 } & NC+PD & CR+PR+MC \\
\hline Type of Variation $^{\mathrm{a}}$ & (no. of patients) & (no. of patients) \\
\hline Up-regulation $_{\text {No change }}$ & 2 & 3 \\
Down-regulation & 2 & 3 \\
\hline
\end{tabular}

aVariations were defined as changes $>30 \%$.

$\mathrm{CR}$, complete response; $\mathrm{PR}$, partial response; $\mathrm{MC}$, minor change; NC, no change; PD, progression of disease.

considered to investigate ER- $\beta$ expression (at an mRNA or protein level), and lack of validated antibodies for immunohistochemistry (Speirs et al. 2002).

In the present study, we investigated whether knowledge of ER- $\beta$ levels could refine the accuracy of ER- $\alpha$ expression in predicting response to hormonal treatment in breast cancer. For this purpose, we planned a neoadjuvant treatment protocol in which a biological study was prospectively associated with the clinical study. The study, that focused on the accrual of elderly patients with immunohistochemically ER- $\alpha$-positive breast cancers, had the advantage of being a clinical trial prospectively designed to answer a specific biological question, i.e. whether ER- $\beta$ is predictive of the response to antiestrogens. Because of the lack of reagents able to reliably detect ER- $\beta$ expression at a protein level, the study was focused on mRNA expression. Although we were aware, when planning the study, of the possibility that messenger level does not necessarily reflect protein expression, we reasoned that a good RNA-based study could contribute more robust data compared with a protein study carried out with antibodies that have not yet been clinically validated. This concept is also indirectly supported by the observation of lower ER- $\alpha$ mRNA levels in less responsive patients, in agreement with previous studies (Dowsett 2003), even though patients had already been selected for ER- $\alpha$ positivity at the protein level. The mRNA study was carried out using a semiquantative RTPCR approach which has already been validated on other biological studies carried out in our laboratory and gave reproducible results (Cappelletti et al. 2003).

In this series of immunohistochemically ER- $\alpha$-positive tumors from elderly patients we observed ER- $\beta$ and ER- $\alpha$ mRNA co-expression at variable levels, and, due to the high sensitivity of the PCR assay, none of the samples could be regarded as frankly negative for ER- $\beta$ expression. However, no biologically relevant correlation was found between ER- $\beta$ mRNA and clinico-pathological variables, except for a direct association with $\mathrm{PgR}$ expression. In the literature, the issue of the relationship between ER- $\beta$ and clinico-pathological or biological variables has been addressed by many studies, detecting protein as well as mRNA on case series including ER- $\alpha$ positive and ER- $\alpha$-negative, or only ER- $\alpha$-positive tumors. Our results are at variance with findings from previous studies, since ER- $\beta$ proved to be associated with good prognosis variables (Jarvinen et al. 2000, Mann et al. 2001, Omoto et al. 2001), with factors indicative of an unfavorable prognosis (Speirs et al. 1999a,b), or not associated with any of the other investigated variables (Palmieri et al. 2002). Our case series is not, however, representative of a general population but of a subgroup of ER- $\alpha$-positive tumors from elderly patients, who are probably characterized by a peculiar biological profile.

To our knowledge, no prospective clinical study addressing the predictive role of ER- $\beta$ on response to hormonal treatment has been carried out, and none of the published retrospective studies has allowed definitive conclusions. The number of ER- $\beta$ predictive and/or prognostic studies is relatively low compared with the high expectancy raised by preclinical data. This could certainly be due to the already mentioned technical problems, as well as to a publication bias due to the reluctance of researchers to submit studies with negative results (Reynolds 2003), despite the need of such studies to overcome underreporting of clinically and biologically useful information.

Neoadjuvant endocrine therapy represents an ideal model to investigate the impact of biomarker expression on tumor response (Ellis 2001). In the present series of ER- $\alpha$-positive (by immunohistochemistry) patients, ER- $\beta$ mRNA failed to provide predictive information to identify elderly patients responsive to preoperative treatment with toremifene. Since biological variables which turn out to be predictive of treatment response in the neoadjuvant setting might also be predictive for response to adjuvant therapy (Ellis 2001), our results would suggest that knowledge of ER- $\beta$ mRNA expression does not add clinically useful information to ER- $\alpha$ status even in the adjuvant setting.

The neoadjuvant setting also makes it possible to test the predictive role of modulations of biological markers on response to treatment. However, in our study neither the type nor the entity of ER modulations was associated with the objective response. However, it should be emphasized that such variations were mainly treatmentrelated, since no time-related variations could be observed in patients with metachronous biopsies from the same lesion, without intercurrent treatment. Furthermore, variations were not related to sampling, as surgical 
samples and ex vivo-obtained core biopsies had comparable ER- $\alpha$ and ER- $\beta$ levels.

A more recent study (Fuqua et al. 2003) confirmed the co-expression of ER- $\alpha$ and ER- $\beta$ also at the protein level and did not provide evidence of any significant correlations with pathobiological parameters, except for a trend of a positive association with aneuploidy. Overall, the outcome of the study was comparable to our results, since in both studies the full length ER- $\beta$ isoform was investigated. One major point raised by the study of Fuqua et al. (2003) was the lack of a correlation between ER- $\beta$ and ER determined by the ligand binding assay, although basic studies performed with recombinant proteins have demonstrated that estradiol has similar binding affinities for the two isoforms (Kuiper et al. 1997). This should indicate that in clinical samples ER- $\beta$ does not contribute to the total specific high affinity binding. Therefore, unless there is a specific binding inhibitor for ER- $\beta$, the only other possibility is that ER- $\beta$ is expressed at very low levels. If this is the case, the role of heterodimers with intermediate low or opposite transcriptional activity could be physiologically not relevant.

Such very low expression of the ER- $\beta$ forms could account for difficulties in obtaining a satisfactory reproducibility and sensitivity in immunohistochemical studies (Skliris et al. 2001) and for inconsistent results regarding its clinical role. Another indirect proof of the relatively low expression of ER- $\beta$ compared with ER- $\alpha$ derives from the modulation profiles of ER- $\alpha$ and ER- $\beta$ following antiestrogen treatment. In fact, it is well known that antiestrogens interact with both isoforms (Kuiper et al. 1997), but our data demonstrated that only the ER- $\alpha$ isoform was consistently down-regulated at the mRNA level in almost all tumors, in keeping with results at the protein level from other presurgical endocrine therapies (Dowsett 2003, Ellis et al. 2003) and as generally expected upon strong stimulation of the receptor by specific ligands. In contrast, ER- $\beta$ was down-regulated in only $50 \%$ of cases, regardless of treatment response. This is further indirect evidence to support the hypothesis that ER- $\beta$ does not participate in modulating antiestrogen effects at the tumor cell level, at least when the prevailing receptor isoform is ER- $\alpha$, whereas it might have a role in other hormone-target tissues, such as prostate and granulosa cells of the ovary, where it is expressed at high levels.

In summary, in this prospective study on a population of elderly patients with ER- $\alpha$-positive breast cancer, the determination of ER- $\beta$ messenger levels was unable to refine the likelihood of response to neo-adjuvant antiestrogen therapy. However, before definitely excluding a predictive role of ER- $\beta$ on the response to hormone therapy, it will also be important to assess the role of ER- $\beta$ splice variants (Nilsson et al. 2001), which are expressed as proteins that may show a preferential heterodimerization with ER- $\alpha$.

\section{Acknowledgements}

We thank B Johnston for editing and preparation of the manuscript. The present work has been financially supported by grants from the Italian Association for Cancer Research (AIRC), the National Research Council (CNR) and the Ministero della Salute (grant 30/03/L0).

\section{References}

Cappelletti V, Saturno G, Miodini P, Koerner W \& Daidone MG 2003 Selective modulation of ER- $\beta$ by estradiol and xenoestrogens in human breast cancer cell lines. Cellular Molecular Life Sciences 60 567-576.

Casini Raggi C, Pinzani P, Paradiso A, Pazzagli M \& Orlandi C 2003 External quality assurance program for PCR amplification of genomic DNA: an Italian experience. Clinical Chemistry 49 782-791.

Cheung KL \& Robertson JFR 2001 Preopertive hormone therapy trials for breast cancer. Breast 10 1-5.

Cowley SM, Hoare S, Mosselman S \& Parker MG 1997 Estrogen receptors $\alpha$ and $\beta$ form heterodimers on DNA. Journal of Biological Chemistry 272 19858-19862.

Dotzlaw H, Leygue F, Watson PH \& Murphy LC 1997 Expression of estrogen receptor-beta in human breast tumors. Journal of Clinical Endocrinology and Metabolism $\mathbf{8 2}$ 2371-2374.

Dotzlaw H, Leygue E, Watson PH \& Murphy LC 1999 Estrogen receptor- $\beta$ messenger RNA expression in human breast tumor biopsies: relationship to steroid receptor status and regulation by progestins. Cancer Research $\mathbf{5 9} 529-532$.

Dowsett M 2003 Preoperative models to evaluate endocrine strategies for breast cancer. Clinical Cancer Research 9 502s-510s.

Early Breast Cancer Trialist Collaborative Group 1992 Systemic treatment of early breast cancer by hormonal, cytotoxic or immune therapy: 133 randomized trials involving 31000 recurrences and 24000 deaths among 75000 women. Lancet 339 1-15, 71-85.

Ellis MJ 2001 Neoadjuvant endocrine therapy for breast cancer: medical perspectives. Clinical Cancer Research 7 4388s-4391s.

Ellis MJ, Coop A, Singh B, Tao Y, Llombart-Cussac A, Janicke F, Mauriac L, Quebe-Fehling E, Chaudri-Ross HA, Evans DB \& Miller WR 2003 Letrazole inhibits tumor proliferation more effectively than tamoxifen independent of HER $1 / 2$ expression status. Cancer Research 63 6523-6531.

Fuqua SAW, Schiff R, Parra I, Moore JT, Mohshin SK, Osborne C K, Clark GM \& Allred DC 2003 Estrogen receptor $\beta$ protein in human breast cancer: correlation with clinical tumor parameters. Cancer Research 63 2434-2439.

Geisler J, Detre S, Berntsen H, Ottestad L, Lindtjorn B, Dowsett M \& Einstein Lonning P 2001 Influence of neoadjuvant anastrazole (Arimidex) on intratumoral estrogen levels and 
proliferation markers in patients with locally advanced breast cancer. Clinical Cancer Research 7 1230-1236.

Goldhirsch A, Glick JH, Gelber RD \& Senn H 1998 Meeting highlights: International Consensus Panel on the Treatment of Primary Breast Cancer. Journal of the National Cancer Institute 90 1601-1608.

Green S, Walter P, Kumar V, Krust A, Bornert JM, Argos P \& Chambon P 1986 Human oestrogen receptor sDNA: sequence, expression and homology to v-erb-A. Nature $\mathbf{3 2 0}$ 134-139.

Hall JM \& McDonnell DP 1999 The estrogen receptor $\beta$-isoform $(\mathrm{ER} \beta)$ of the human estrogen receptor modulates ER $\alpha$ transcriptional activity and is a key regulator of the cellular response to estrogens and antiestrogens. Endocrinology 140 5566-5578.

Jarvinen T, Pelto-Huikko M, Holli K \& Isola J 2000 Estrogen receptor $\beta$ is coexpressed with $\mathrm{ER} \alpha$ and associated with nodal status, grade, and proliferation rate in breast cancer. American Journal of Pathology 156 29-35.

Kuiper G, Enmark E, Pelto-Huikko M, Nilsson S \& Gustafsson JA 1996 Cloning of a novel receptor expressed in rat prostate and ovary. PNAS 93 5925-5930.

Kuiper GG, Carlsson B, Grandien K, Enmark E, Haggblad J, Nilsson S \& Gustafsson JA 1997 Comparison of the ligand binding specificity and transcript tissue distribution of estrogen receptors $\alpha$ and $\beta$. Endocrinology 138 863-870.

Mann S, Laucirica R, Carlson N, Younes PS, Ali N, Younes A, Li Y \& Younes M 2001 Estrogen receptor beta expression in invasive breast cancer. Human Pathology 32 113-118.

Moliterni A, Menard S, Valagussa P, Biganzoli E, Boracchi P, Balsari A, Casalini P, Tomasic G, Marubini E, Pilotti S \& Bonadonna G 2003 HER2 overexpression and doxorubicin in adjuvant chemotherapy for resectable breast cancer. Journal of Clinical Oncology 21 458-462.

National Institutes of Health Consensus Development Conference statement: Adjuvant Therapy for Breast Cancer 2001, November 1-3, 2000. Journal of the National Cancer Institute Monographs 30 5-15.

Nilsson S, Makela S, Treuter E, Tujague M, Thomsen J, Andersson G, Enmark E, Pettersson K, Warner M \& Gustafsson JA 2001 Mechanism of estrogen action. Physiological Reviews 81 1535-1565.

Omoto Y, Inoue S, Ogawa S, Toyama T, Yamashita H, Muramatsu M, Kobayashi S \& Iwase H 2001 Clinical value of wild-type estrogen receptor beta expression in breast cancer. Cancer Letters 163 207-212.

Paech K, Webb P, Kuiper GG, Nilsson S, Gustafsson J, Kushner PJ \& Scanlan TS 1997 Differential ligand activation of estrogen receptors ERalpha and ERbeta at AP1 sites. Science 277 1508-1510.

Palmieri C, Cheng GJ, Saji S, Zelada-Hedman M, Warri A, Weihua Z, Van Noorden S, Wahlstrom T, Coombes RC,
Warner M \& Gustafsson JA 2002 Estrogen receptor beta in breast cancer. Endocrine-Related Cancer 9 1-13.

Paradiso A, Volpe S, Iacobacci A, Marubini E, Verderio P, Costa A, Daidone MG, Marchetti A, Mottolese M, Amadori D, De Paola F, Saragoni L, Medri L, Nenci I, Querzoli P, Gion M, Dittami R, Plebani, Orlando C, Bevilacqua G \& Silvestrini R; Italian Network for Quality Assessment of Tumor Biomarkers 2002 Quality control for biomarker determination in oncology: the experience of the Italian Network for Quality Assessment of Tumor Biomarkers (INQAT). International Journal of Biological Markers 17 201-214.

Peto R 2000 Trends in breast cancer incidence, survival and mortality. Lancet 356 590-593.

Pettersson K, Delaunay F \& Gustafsson JA 2000 Estrogen receptor $\beta$ acts as a dominant regulator of estrogen signalling. Oncogene 19 4970-4978.

Reynolds T 2003 Researchers push for publication, registration of all clinical trials. Journal of the National Cancer Institute 95 772-774.

Simon R 1989 Optimal two-stage designs for phase II clinical trials. Controlled Clinical Trails 10 1-10.

Skliris GP, Carder PJ, Lansdown MR \& Speirs V 2001 Immunohistochemical detection of ER $\beta$ in breast cancer: towards more detailed receptor profiling? British Journal of Cancer 84 1095-1098.

Skliris GP, Parkes AT, Limer JL, Burdall SE, Carder PJ \& Speirs V 2002 Evaluation of seven oestrogen receptor $\beta$ antibodies for immunohistochemistry, western blotting, and flow cytometry in human breast tissue. Journal of Pathology 197 $155-162$.

Speirs V 2002 Oestrogen receptor $\beta$ in breast cancer: good, bad or still too early to tell? Journal of Pathology 197 143-147.

Speirs V, Parkes A, Kerin MJ, Walton DS, Carleton PJ, Fox JN $\&$ Atkin SL $1999 a$ Coexpression of estrogen receptor $\alpha$ and $\beta$ : poor prognostic factors in human breast cancer? Cancer Research 59 525-528.

Speirs V, Malone C, Walton DS, Kerin MJ \& Atkin SL $1999 b$ Increased expression of estrogen receptor $\beta$ mRNA expression in tamoxifen-resistant breast cancer patients. Cancer Research 59 5421-5424.

Speirs V, Carder PJ \& Landsdown MRJ 2002 Oestrogen receptor beta: how should we measure this? British Journal of Cancer 87687 (letter).

Speirs V, Carder PJ, Lane S, Dodwell D, Lansdown RJ \& Hanby AM 2004 Oestrogen receptor $\beta$ : what it means for patients with breast cancer. Lancet Oncology 5 174-181.

Veronesi U, Paganelli G, Viale G, Luini A, Zurrida S, Galimberti $\mathrm{V}$, Intra M, Veronesi P, Robertson C, Maisounneuve P, Renne G, De Cicco C, De Lucia F \& Gennari R 2003 A randomized comparison of sentinel-node biopsy with routine axillary dissection in breast cancer. New England Journal of Medicine 349 546-553. 